\title{
Development of a fish-based index for the assessment of the ecological status of Lake Balaton in the absence of present day reference condition
}

\author{
András Specziár ${ }^{*}$ and Tibor Erős \\ Balaton Limnological Institute, Centre for Ecological Research, Klebelsberg Kuno utca 3, 8237 Tihany, Hungary
}

Received: 4 October 2019 / Accepted: 13 January 2020

\begin{abstract}
A fish-based index is proposed to indicate the ecological status of Lake Balaton, Hungary in accordance with the standard of the European Water Framework Directive (WFD). The Balaton fish index (BFI) synthetises information of 13 lake-specific fish metrics including gillnetting and electric fishing data of species richness of native assemblages, relative abundance, biomass and age structure of native key species, representation of non-native species and general health status. The main anthropogenic pressures considered were the degradation of littoral habitats, invasion of non-native fish species, eutrophication and fishing/angling including stocking. Ecological quality ratio (EQR) is assessed by relating actual fish assemblage metrics to the supposed undisturbed reference status of Lake Balaton reconstructed by expert judgement based on recent and historic information on the fish fauna and its changes. Values of BFI were consistent and indicated good ecological status of Lake Balaton in the period of 2005-2018. This study provides an example on how an EQR assessment methodology might be established in unique habitats with no possibilities for statistical evaluation of pressure-respond relationships and exact determination of the reference status.
\end{abstract}

Keywords: Biological quality element fish / biotic integrity / EQR / European Water Framework Directive / fish assemblage

Résumé - Élaboration d'un indice basé sur les poissons pour l'évaluation de l'état écologique du lac
Balaton en l'absence de conditions de référence actuelles. Un indice basé sur les poissons est proposé
pour indiquer l'état écologique du lac Balaton, en Hongrie, conformément à la norme de la directive-cadre
européenne sur l'eau (DCE). L'indice des poissons du Balaton (BFI) synthétise les informations de 13
métriques de poissons spécifiques au lac, y compris les données de pêche au filet maillant et de pêche
électrique sur la richesse en espèces des assemblages indigènes, l'abondance relative, la biomasse et la
structure par âge des principales espèces indigènes, la représentation des espèces non indigènes et l'état de
santé général. Les principales pressions anthropiques prises en compte étaient la dégradation des habitats
littoraux, l'invasion d'espèces de poissons non indigènes, l'eutrophisation et la pêche et l'ensemencement.
Le rapport de qualité écologique (EQR) est évalué en établissant un lien entre les mesures réelles des
assemblages de poissons et l'état de référence supposé non perturbé du lac Balaton, reconstruit par un
jugement d'expert basé sur des informations récentes et historiques sur la faune piscicole et ses
changements. Les valeurs du BFI étaient cohérentes et indiquaient un bon état écologique du lac Balaton
pour la période de 2005 à 2018 . Cette étude fournit un exemple de la façon dont une méthode d'évaluation de
l'EQR pourrait être établie dans des habitats uniques sans possibilité d'évaluation statistique des relations
pression-réponse et de la détermination exacte de l'état de référence.

Mots clés : Poisson / intégrité biotique / EQR / Directive cadre européenne sur l'eau / communautés de poissons

\footnotetext{
*Corresponding author: specziar.andras@okologia.mta.hu
} 


\section{Introduction}

Fish are one of the key organisms in majority of freshwater ecosystems; they represent high taxonomic and functional diversity, and are important components of the aquatic food web participating at all consumer levels from primary consumers to top predators, and to decomposers (Wootton, 1998). Fish assemblages respond sensitively to environmental changes, and thus, qualitative and quantitative properties of their assemblages can be effectively used as indicators of environmental degradation (Karr, 1981; Poikane et al., 2017). Accordingly, the European Water Framework Directive (WFD) considers fish as an important biological quality element (BQE) and suggests fish-based assessment of ecological status in aquatic ecosystems (EC, 2000). As a consequence, a significant research effort has been expended for the development of fish-based indices for European inland waters (Pont et al., 2007; Schmutz et al., 2007; Launois et al., 2011; Olin et al., 2013; Ritterbusch et al., 2014; Kelly and Harrison, 2016; Blabolil et al., 2016).

The WFD stipulates that the ecological status of the evaluated water bodies have to be assessed by quantifying the deviation between present day ecological status and natural (or near natural) reference status in the absence of human perturbation effects (i.e. the so called ecological quality ratio, EQR). For the determination of reference status several approaches are used including: (i) the reference site approach, which uses existing pristine or minimally disturbed sites as a benchmark; (ii) best professional judgment, which uses expert knowledge to establish reference status; (iii) the historical condition approach, which uses historical data to reconstruct reference status; (iv) extrapolation of empirical models using environmental and pressure gradients; (v) ambient distributions, which uses expert based interpretations of the range of metric values to define the reference status (Stoddard et al., 2006; Birk et al., 2012).

The determination of ecological status is especially difficult in habitats with unique abiotic conditions and ecological assemblages for which no present day type-specific reference sites can be found (Gassner et al., 2005). Here, best professional judgement, historical data, and the use of the ambient distribution of metric values are the sole options to assess ecological status (Poikane et al., 2015). This is the situation with many European lakes, the fish-based assessment of which ecosystems lack behind streams and rivers, and has just recently been recognized as a great research and water political need (Poikane et al., 2015). In fact, determination of the ecological status of natural lakes (i.e. not artificial water bodies, like reservoirs) largely focused on the use of algae and for the determination of eutrophication effects (Birk et al., 2012; Poikane et al., 2015). However, most large natural lakes are intensively utilized by fishing, where balancing between the maintenance of good ecological status and sustainable fisheries (as an important ecosystem service) is a big challenge of water resources management.

The situation of Lake Balaton is similar; Balaton is the sole representative of plain region, calcareous, very large, medium deep, permanent lakes (HU type L1) in Hungary as well as in the area of the Eastern Continental Lake Geographical Intercalibration Group. Lake Balaton represents nearly half

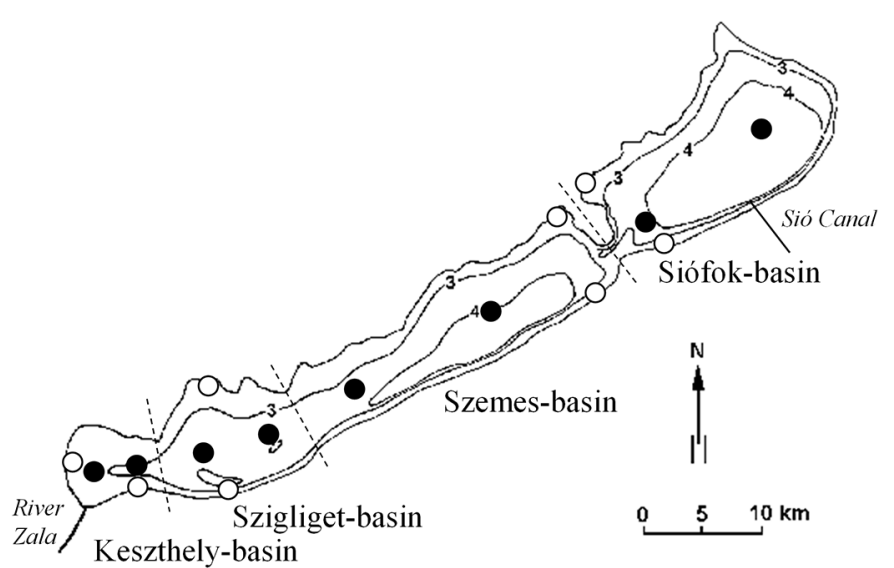

Fig. 1. Distribution of sampling sites $(\mathbf{O}$, offshore gillnetting sites; $\bigcirc$ littoral gillnetting and electric fishing sites).

of the total surface area of natural aquatic habitats in the Pannonian Ecoregion, and thus, its ecological status may affect biotic diversity and biotic integrity region-wide. Accordingly, the area of the lake is included to the Natura 2000 network and part of the Balaton-felvidéki National Park. Moreover, Lake Balaton inhabits significant populations of Habitat Directive (EC, 1992) Annex II. fish species, the asp Leuciscus aspius (L.), the razor fish Pelecus cultratus (L.), the white-finned gudgeon Romanogobio vladykovi Fang and the bitterling Rhodeus sericeus (Pallas). Similarly to most European lakes located in populated areas (EEA, 2012; Poikane et al., 2017), biotic integrity of Lake Balaton is subjected to multiple anthropogenic pressures, such as degradation of littoral habitats, invasion of non-native fish species, eutrophication, and fishing including stocking (Virág, 1998; Bíró, 1997; Istvánovics et al., 2007; Specziár, 2010). Although standardised sampling of fish assemblages started in the late 1990s and are performed according to recommendations of the WFD since 2005 (Specziár, 2010), the methodology of fish-based assessment of ecological status of Lake Balaton has not been developed yet.

The aim of this study is to present a methodology for fishbased assessment of the ecological status of Lake Balaton. Our specified goals were: (i) to identify lake-specific metrics that are sensitive for the main anthropogenic pressures and supported by standardised gillnetting and electric fishing surveys; (ii) to assess the reference (undisturbed) fish community of Lake Balaton; and (iii) to implement the selected metrics into a meaningful EQR index. This study provides an example on how an EQR assessment methodology might be established in unique habitats with no possibilities for statistical evaluation of pressure-respond relationships and exact determination of the reference status.

\section{Materials and methods}

\subsection{Study area}

Balaton is the largest shallow lake (surface area: $596 \mathrm{~km}^{2}$; mean depth: $3.2 \mathrm{~m}$ ) in Central Europe, situated at $46^{\circ} 42^{\prime}-47^{\circ}$ $04^{\prime} \mathrm{N}, 17^{\circ} 15^{\prime}-18^{\circ} 10^{\prime} \mathrm{E}$ and $104.8 \mathrm{~m}$ above sea level (Fig. 1). 
The lake is slightly alkaline $\left(400 \mathrm{mg}^{-1}\right.$ of $\mathrm{Ca}^{2+}$ and $\left.\mathrm{Mg}^{2+}\left(\mathrm{HCO}_{3}^{-}\right)_{2}\right)$ with a decreasing trophic gradient (i.e. chlorophyll-a concentration from 9.6 to $3.9 \mu \mathrm{g} 1^{-1}$, mean data of 2013-2014; Ministry of Environmental Protection and Water Management of Hungary, http:/www.ktm.hu/balaton/ lang_en/index.htm) from SW to NE along its longitudinal axis (see also Istvánovics et al., 2007). Its $\mathrm{pH}$ varies between 8.2 and 9.1, and has a conductivity of $550-671 \mu \mathrm{s} \mathrm{cm}^{-1}$ (Specziár and Vörös, 2001). In general the lake is turbid with a Secchi depth varying between $0.2 \mathrm{~m}$ and $1.8 \mathrm{~m}$. More than $85 \%$ of the total lake area is macrophyte free open water and most of the habitat heterogeneity concentrates in the littoral zone. Today only about $47 \%$ of the lake shore is covered by emergent macrovegetation (dominanted by common reed Phragmites australis (Cav.) Trin. ex Steud.), while the density of submerged macrohytes varies considerably annually in the littoral zone. Significant sections $(>50 \%)$ of the shore have been covered with concrete and rocks. Several large, and many small boat harbours were built along the lake for commercial and recreational purposes.

\subsection{Fish sampling}

Fish assemblage sampling is performed according to a standardised protocol since 2005. This protocol was developed based on the recommendations of the concerning European standards (CEN, 2003, 2005) and their adjustment to local conditions (Specziár, 2010).

Main gears of sampling are multi-mesh gillnets compatible with the European standard EN 14757 (CEN, 2005) and are composed of 12 conventional mesh-sizes between 5 and $55 \mathrm{~mm}(43,19.5,6.25,10,55,8,12.5,24,15.5,5,35$ and $29 \mathrm{~mm}$; knot to knot) and two larger mesh-sizes (65 and $80 \mathrm{~mm}$ ). Addition of larger mesh-size panels is needed in habitats where larger $(>500 \mathrm{~g})$ fish are common (Specziár, 2010; ك̌mejkal et al., 2015). Each mesh-size panel is $2.5 \mathrm{~m}$ long and the whole net has a total length of $35 \mathrm{~m}$. In order to sample the whole water column at all water depth, which is essential for a representative monitoring (Lauridsen et al., 2008; Specziár et al., 2009, 2013; Alexander et al., 2015), three versions of this gillnet setup is used in Lake Balaton. The standard benthic (nordic-type) gillnet (BG) is $1.5 \mathrm{~m}$ high and weighted to ensure dipping of the lead line to the bottom. This net is used at all sampling sites in triplicate to ensure Europewide comparability. At sites with $>1.5 \mathrm{~m}$ water depth, the $3 \mathrm{~m}$ high version of the standard benthic gillnet (DHBG) is also used in triplicate. Finally, at sites with $>3 \mathrm{~m}$ water depth, the surface-set version of the $1.5 \mathrm{~m}$ high standard gillnet (SG) is also used in triplicate. Therefore, minimum number of gillnets set per site at $\leq 1.5 \mathrm{~m}$ water depth is three (only $\mathrm{BG}$ ), at water depth between 1.5 and $3 \mathrm{~m}$ is six $(3 \times \mathrm{BG}$ and $3 \times \mathrm{DHBG})$ and at water depth $>3 \mathrm{~m}$ is nine $(3 \times \mathrm{BG}, 3 \times \mathrm{DHBG}$ and $3 \times \mathrm{SG})$.

Considering the biased catchability of fish in the spawning season and at low water temperatures (Specziár, 2001), sampling is scheduled between August and September. Because gillnet catches are relatively high in Lake Balaton, soak time must be kept short (Specziár et al., 2009) to avoid the saturation of nets by fish and the related sampling bias (CEN, 2005; Prchalová et al., 2011). Consequently, gillnets are set in the morning (after sunrise) for 1-3 hours of operation. At a
Table 1. Area weights for gillnetting sites.

\begin{tabular}{lllll}
\hline & $\begin{array}{l}\text { Southern } \\
\text { littoral } \\
\left(\mathrm{km}^{2}\right)\end{array}$ & $\begin{array}{l}\text { Offshore } \\
\left(\mathrm{km}^{2}\right)\end{array}$ & $\begin{array}{l}\text { Northern } \\
\text { littoral } \\
\left(\mathrm{km}^{2}\right)\end{array}$ & $\begin{array}{l}\text { Total } \\
\left(\mathrm{km}^{2}\right)\end{array}$ \\
\hline Keszthely-basin & 5.3 & 26.5 & 8.2 & 40.0 \\
Szigliget-basin & 7.3 & 96.0 & 6.7 & 110.0 \\
Szemes-basin & 10.1 & 189.0 & 11.9 & 211.0 \\
Siófok-basin & 8.5 & 212.0 & 11.5 & 232.0 \\
Lake Balaton & 31.2 & 523.5 & 38.3 & 593.0
\end{tabular}

minimum, 16 sampling sites distributed across the four basins of the lake are surveyed (Fig. 1). Catch of each net is processed separately. All captured fish are identified, checked for abnormalities, and counted and measured for total biomass with a precision of $1 \mathrm{~g}$ by species.

Based on catch-per-unit-effort data of individual nets (CPUE, number or biomass of fish captured by a net in one hour of fishing) the whole lake average $C P U E_{\text {Balaton }}$ is calculated as follows. First, a whole water column $C P U E_{W C}$ (number or biomass of fish captured per standard gillnetting effort, where standard gillnetting effort represents one hour of fishing with a standard gillnet setup -14 mesh sizes, $2.5 \mathrm{~m}$ long each - covering the whole water column) is calculated for each sampling site. $C P U E_{W C}$ equals $C P U E_{B G}$ at $\leq 1.5 \mathrm{~m}$ water depth and $C P U E_{D H B G}$ at water depth between 1.5 and $3 \mathrm{~m}$, whereas for sites with water depth $>3 \mathrm{~m}$ it is calculated as $C P U E_{W C}=C P U E_{D H B G}+C P U E_{S G} \times \frac{h-3}{1.5}$, where $C P U E_{B G}$, $C P U E_{D H B G}$ and $C P U E_{S G}$ are the CPUEs for the BG, DHBG and SG nets, respectively, while $h$ is the water depth in meter. Then, the whole lake CPUE $E_{\text {Balaton }}$ (number or biomass of fish captured per standard gillnetting effort) is calculated as the weighted average of $C P U E_{W C}$ values of all sites: $C P U E_{\text {Balaton }}=\sum_{i=1}^{16} C P U E_{W C, i} \times \frac{A_{i}}{A_{\text {Balaton }}}$, where, $C P U E_{W C, i}$ is the whole water column $C P_{U E}$ for sampling site $i, A_{i}$ is the lake area represented by the sampling site $i\left(\mathrm{~km}^{2}\right.$; Tab. 1), while $A_{\text {Balaton }}$ is the total area of Lake Balaton $\left(593 \mathrm{~km}^{2}\right)$. Weighting is necessary because sampling sites are distributed nonrandomly, and the abundance and structure of fish assemblages vary significantly between habitats (i.e. northern littoral, southern littoral and offshore) and along the longitudinal axis of Lake Balaton (Specziár, 2010; Specziár et al., 2013). The boundary of the littoral zone was set at $2.1 \mathrm{~m}$ water depth and then the area related to each sampling site was measured on the NaviGuide Hungary v3.1 map shape (Navi-Gate Kft., www.garmin.hu) using the MapSource 6.10.1 software (Garmin Ltd., www.garmin.hu).

Reed grass stands in the littoral zone are sampled with daytime electric fishing using a battery-powered machine (Hans-Grassl IG 200-2B). The cathode, a $5 \mathrm{~m}$ long copper cable, is floated at the rear of the boat. To allow effective manoeuvring in the reed, a small rubber boat (Yamaha 300S) with an electric engine is used. The crew comprised two persons: one for catching the fish with the hand-held anode ( $2.5 \mathrm{~m}$ long pole with a net of $40 \mathrm{~cm}$ diameter, mesh size $6 \mathrm{~mm}$ ) 
and one for driving the boat. Continuous electrofishing is carried out by dipping the anode into the water at approximately $3 \mathrm{~m}$ long intervals and pulling the anode toward the boat, while moving slowly ahead (Erös et al., 2009). At least five $100 \mathrm{~m}$ long sections are sampled at a minimum of eight sampling sites distributed in the northern and southern littoral zones of the four main lake basins (Fig. 1). All captured fish are identified, checked for abnormalities, and counted by species. CPUE is expressed in number of fish captured per $100 \mathrm{~m}$, and the whole lake CPUE is calculated as simple average of site-specific CPUEs.

Hereafter, all CPUE values are whole lake averages and may represent catch in number (NPUE) or in biomass (BPUE).

Age structure and health status of the native species were graded on a three-category scale (balanced, partly unbalanced and unbalanced for age structure; and good, moderate and bad for health status) by expert judgement on length frequency distribution and on external signs of diseases, parasites and malformations, respectively. Age structure of a species is considered to be unbalanced when either juvenile or older age classes are missing or substantially underrepresented.

\subsection{Data base}

Fish data were obtained from two sources. Monitoring data based on the above described sampling protocol are available for the period 2005-2009 (one to five sampling occasions per sites), and for years 2010, 2012, 2013, 2014 (only gillneting data) and 2018 (Specziár and Takács, 2007; Specziár, 2010; this study). For the reconstruction of the reference fish assemblage of Lake Balaton, we also utilized non-representative species occurrence reviews published since the late $1800 \mathrm{~s}$ (Herman, 1887; Daday, 1897; Vutskits, 1897; Unger, 1925; Hankó, 1931; Lukács, 1932; Entz and Sebestyén, 1942; Bíró, 1981, 1997; Specziár et al., 2000; Specziár, 2010; Appendix 1).

\subsection{Index development}

Our methodological approach utilises the theory of biological integrity of aquatic ecosystems (Karr, 1981) and, in harmony with the requirement of the WFD (EC 2000), it evaluates the deviation between present and reference conditions of the ecosystem of Lake Balaton (i.e. the ecological quality ration, EQR). Our goal was to select a set of fish-based metrics supported by the above-described monitoring protocol and by historic species lists, which provide a representative picture about the ecological status of fish assemblages as well as of the ecosystem of Lake Balaton, and which could be integrated into an effective EQR index.

Based on historic species lists, recent structure of native fish assemblages in the lake and in subsistent wetlands areas that formerly belonged to Lake Balaton, and evaluation of probable effects of present and past pressures, we defined major features of the reference status. We determined the key functional species and the most sensitive species group of the native fish fauna. Then, based on expert judgement we selected the most relevant and robust fish-based metrics which are likely to respond to the identified pressures (degradation of littoral habitats, invasion of non-native fish species, eutrophication and fishing/angling) of the region. Metrics were selected as to represent most important taxonomic and functional features of the fish assemblage, such as diversity of native species, occurrence of sensitive native species, population status of the key species, representation of nonnative components, and recruitment and health status of the native species. Robustness to sampling effort, representativity and bias were also important criteria of metric selection (Deceliere-Vergés et al., 2009; Specziár et al., 2009; Zale et al., 2013). Therefore, metrics focusing on the key species and species groups, but underweighting rare elements of the fauna were preferred. Finally, the scoring table of each selected metric was set individually and relative to the hypothetical value of the given metric at the reference status (i.e. ambient scoring method). Maximum score of each metric was weighted according to the relative importance of pressure effect they supposed to indicate and their sum totalling 100.

\section{Results}

\subsection{Assessment of the reference status}

We assume that the core assemblage (populations that accomplish complete life cycle in the lake) of the original fish fauna of Lake Balaton was composed by the native fish species with permanent populations at the present, and by mudminnow Umbra krameri Walbaum, weatherfish Misgurnus fossilis L., crucian carp Carassius carassius (L.), spined loach Cobitis elongatoides Băcescu and Mayer, and burbot Lota lota (L.), which occurred in the historical data set (Appendix 1). Since we do not have quantitative historical data, assessment of the relative abundances of these species for the reference status is, however, a much more difficult task. Accordingly, we assume that littoral species, and especially the phytophilous species, could be much more abundant in the past, whereas offshore species occurred in the same or just slightly higher densities than today, except the pikeperch Sander lucioperca (L.), the population of which species is being under a strong angling pressure at present. Monitoring data on relative fish abundance are summarized in Figures 2 and 3.

\subsection{Selected metrics of the EQR}

Thirteen fish based metrics (M1-M13) were selected to indicate the response of fish assemblages for specific pressures (i.e. degradation of littoral habitats, invasion of non-native fish species, eutrophication and intensive angling) and to assess the ecological status of Lake Balaton (Tab. 2).

\subsubsection{M1. Number of abundant (eNPUE $>0.1$ ind. $100 \mathrm{~m}^{-1}$ ) native species in the electric fishing samples}

Natural littoral habitats represent high environmental heterogeneity and support high fish diversity. Consequently, any loss in the species richness may indicate habitat degradation or other pressure effect. In order to provide a robust indication, rare species (less than four individuals captured at a minimal sampling intensity of 8 sites $\times$ 5 replicates of 100 sampling stretch) with low detectability are excluded from the calculation. List of the permanent native species for the reference state is given in Appendix 1 . 


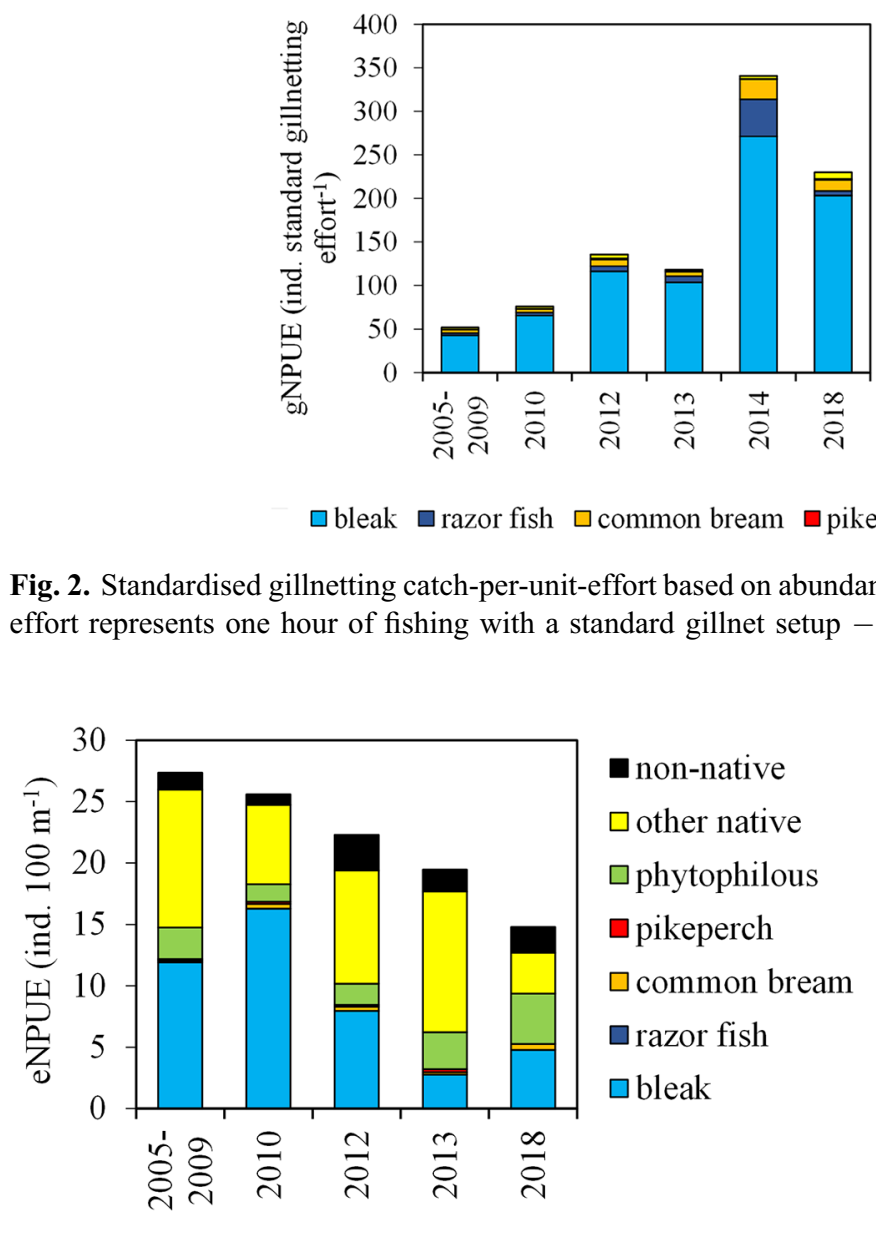

Fig. 3. Standardised electric fishing catch-per-unit-effort based on abundance (eNPUE) in the littoral zone of Lake Balaton.

3.2.2 M2. Relative abundance of phytophilous native species in the electric fishing samples $\left(\right.$ eNPUE $_{\text {phyt. }} \times$ eNPUE $\left._{\text {total }}{ }^{-1}\right)$

Native species with strong preference to macrophyte dominated habitats are especially sensitive to ecological quality of the littoral zone. List of the permanent native phytophilous species for the reference state is given in Appendix 1.

\subsubsection{M3. Relative abundance of non-native species in the electric fishing samples (eNPUE ${ }_{\text {non-native }} \times$ eNPUE $_{\text {total }}{ }^{-1}$ )}

High abundance of non-native species may indicate a strong anthropogenic impact on the ecosystem. Moreover, the presence of non-native species represent a significant threat on native biodiversity and ecosystem functioning. This metric indicates non-native species infection in the littoral zone.

3.2.4 M4. Number of abundant (gNPUE $>0.2$ ind. standard gillnetting effort ${ }^{-1}$ ) native species in the gillnetting samples

Decreased native species richness may indicate habitat degradation or other pressure effect. In order to provide a robust indication, rare species with low detectability are

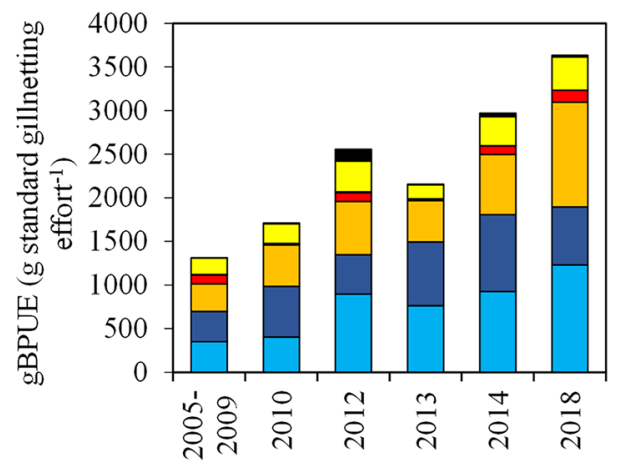

Fig. 2. Standardised gillnetting catch-per-unit-effort based on abundance (gNPUE) and biomass (gBPUE) in Lake Balaton. Standard gillnetting

excluded from the calculation. List of the permanent native species for the reference state is given in Appendix 1.

\subsubsection{M5. Relative abundance of non-native species in the gillnetting samples $\left(\right.$ gNPUE $_{\text {non-native }} \times$ gNPUE $\left._{\text {total }^{-1}}{ }^{-1}\right)$}

Large- and small-sized non-native species may represent different functionality, and therefore, impact the ecosystem differently. This abundance based metric concentrates on the ecological impact related to small-sized non-native species.

\subsubsection{M6. Relative biomass of non-native species in the} gillnetting samples $\left(\mathrm{gBPUE}_{\text {non-native }} \times \mathrm{gBPUE}_{\text {total }^{-1}}{ }^{-1}\right)$

Compared to M5, this biomass based metric concentrates on the ecological impact related to large-sized non-native species.

\subsubsection{M7. Relative biomass of common carp Cyprinus carpio $\mathrm{L}$. in the gillnetting samples $\left(\right.$ gBPUE $_{\text {carp }} \times$ gBPUE $\left._{\text {total }^{-1}}\right)$}

Common carp is native in Lake Balaton, however, angling oriented fisheries management is motivated to increase density of common carp by regular stockings. Increased density of common carp indicates a strong anthropogenic impact and represent a threat for other native species as well as influences the functioning of the ecosystem. Therefore, both a too low and a too high common carp density could indicate some pressure effect.

\subsubsection{M8. Gillnetting BPUE of the razor fish (gBPUE ${ }_{\text {razor fish) }}$}

Razor fish is a key fish species of Lake Balaton, which makes the lake fish fauna unique, and different from other European lakes. It has a specialised planktivorous feeding, unique pelagophilous reproduction, and sensitivity to eutrophication, intensive fishing and probably several other pressures. Moreover, razor fish is listed in Annexes 2. and 5. of the Natura 2000 (EC 1992). 
A. Specziár and T. Erős: Knowl. Manag. Aquat. Ecosyst. 2020, 421, 11

Table 2. Fish-based metrics comprising the Balaton fish index (BFI) assessing the ecological quality ratio (EQR) of Lake Balaton, their categories and scoring by categories. eNPUE (ind. $100 \mathrm{~m}^{-1}$ ), catch per unit effort by number in electric fishing samples; gNPUE (ind. standard gillnetting effort ${ }^{-1}$ ) and gBPUE ( $\mathrm{g}$ standard gillnetting effort ${ }^{-1}$ ), catch per unit effort by number and biomass in gillnetting samples; standard gillnetting effort represents one hour of fishing with a standard gillnet setup - 14 mesh sizes, $2.5 \mathrm{~m}$ long each - covering the whole water column. Native, native phytophilous (phyt.), native key species and non-native species are listed in Appendix 1.

\begin{tabular}{|c|c|c|c|c|c|c|c|c|}
\hline \multirow[t]{2}{*}{ Metrics } & \multicolumn{4}{|c|}{ Metric categories } & \multicolumn{4}{|c|}{ Scoring by category } \\
\hline & 1 & 2 & 3 & 4 & 1 & 2 & 3 & 4 \\
\hline
\end{tabular}

Electric fishing samples

1. $\mathrm{n}_{\text {native }}$ with eNPUE $\geq 0.1$ ind. $100 \mathrm{~m}^{-1}$

2. eNPUE $_{\text {phyt. }}$ eNPUE total $^{-1}$

3. eNPUE ${ }_{\text {non-native }}$ eNPUE $_{\text {total }}{ }^{-1}$

$\begin{array}{llllllll}<8 & 8-10 & 11-12 & 13 \leq & 0 & 3 & 7 & 10 \\ <0.05 & 0.05-0.15 & 0.15-0.25 & 0.25 \leq & 0 & 3 & 7 & 10 \\ <0.01 & 0.01-0.1 & 0.1-0.25 & 0.25 \leq & 10 & 7 & 3 & 0\end{array}$

Gillnetting samples

4. $n_{\text {native }}$ with gNPUE $\geq 0.2$ ind. standard

gillnetting effort ${ }^{-1}$

5. gNPUE ${ }_{\text {non-native }}$ gNPUE $_{\text {total }}{ }^{-1}$

6. gBPUE ${ }_{\text {non-native }}$ gBPUE $_{\text {total }}{ }^{-1}$

7. gBPUE $_{\text {carp }}$ gBPUE $_{\text {total }}{ }^{-1}$

8. gBPUE razor fish $_{\text {. }}$

9. gBPUE $_{\text {pikeperch }}$ gBPUE $_{\text {total }^{-1}}$

10. gBPUE bream

11. gBPUE total

$\begin{array}{llllllll}<4 & 4-6 & 7-8 & 9 \leq & 0 & 3 & 7 & 10 \\ <0.01 & 0.01-0.1 & 0.1-0.25 & 0.25 \leq & 5 & 3 & 1 & 0 \\ <0.01 & 0.01-0.1 & 0.1-0.25 & 0.25 \leq & 10 & 7 & 3 & 0 \\ <0.001 & 0.001-0.01 & 0.01 \leq & & 0 & 5 & 0 & \\ <20 & 20-200 & 200-1000 & 1000 \leq & 0 & 5 & 10 & 5 \\ <0.01 & 0.01-0.04 & 0.04-0.08 & 0.08 \leq & 0 & 5 & 10 & 5 \\ <300 & 300-1200 & 1200 \leq & & 0 & 5 & 0 & \\ <1000 & 1000-4000 & 4000 \leq & & 0 & 5 & 0 & \end{array}$

Electric fishing and gillnetting samples

12. Age structure (balanced: balanced in all native key species and in all other native species with exception

Balanced Partly Unbalanced unbalanced

Unbalanced 53

0 of no more than two; partly unbalanced: unbalanced in one key species or at least in three other native species; unbalanced: unbalanced at least in two native key species) 13. Health status (good: $<5 \%$ of individuals show any sign of diseases, heavy infection by parasites, malformations and hybridisation; 5-20\% of individuals show some signs of these abnormalities; bad: $>20 \%$ of individuals are affected).

3.2.9 M9. Relative biomass of pikeperch in the gillnetting samples $\left(\mathrm{gNPUE}_{\text {pikeperch }} \times \mathrm{gNPUE}_{\text {total }}{ }^{-1}\right)$

Pikeperch is the most abundant, native top predator fish in Lake Balaton. Consequently, either a significant decrease or significant increase in its population density - which, similarly to carp is stocked regularly to fulfil the demand of anglers may indicate ecosystem level pressure effects.

\subsubsection{M10. Gillnetting BPUE of the common bream Abramis brama (L.) (gBPUE bream $_{\text {) }}$}

Common bream is one of the most abundant native fish species in Lake Balaton. It utilizes both benthic and pelagic food resources, and is sensitive to the status of littoral spawning habitats, eutrophication and other pressures. Either a significant decrease or a significant increase of common bream density could indicate anthropogenic impact.

\subsubsection{M11. Total gillnetting BPUE (gBPUE ${ }_{\text {total }}$ )}

Several pressures effecting the ecosystem may alter total fish density. Both a significant decrease and a significant increase in the fish density could indicate anthropogenic impact.

\subsubsection{M12. Age structure of native species}

Unbalanced age structure could indicate unfavourable or changing ecological status. Since the assessment of age structure requires large sample sizes, this metric is based primarily on population data of the most abundant key species, with diverse ecological functions and it is assessed from combined gillnetting and electric fishing samples. These species are the bleak Alburnus alburnus (L.), the razor fish, the common bream and the pikeperch.

\subsubsection{M13. Health status}

Health status of fish is assessed according to percentage of individuals with visible external signs of diseases, heavy infection by parasites, malformations and hybridisation in combined gillnetting and electric fishing samples. Although some health problem may present even in natural assemblages, its more general occurrence likely is an indication of unfavourable ecological processes. 


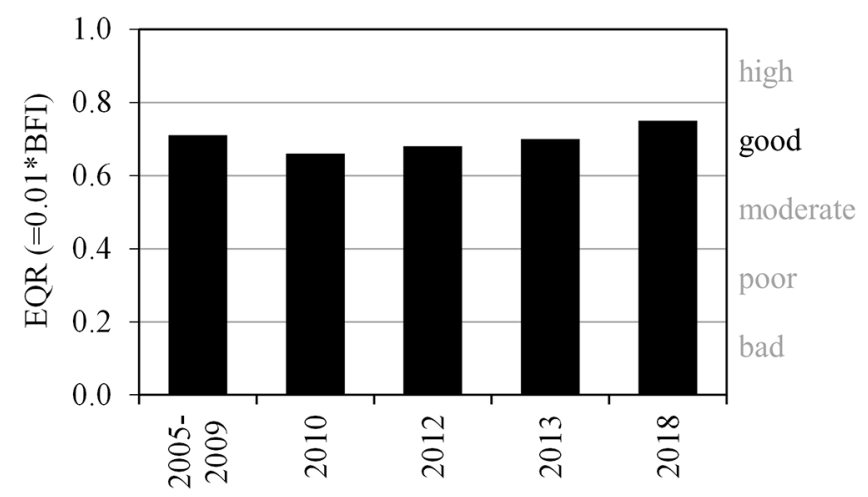

Fig. 4. Ecological quality ratio (EQR) of Lake Balaton assessed by the Balaton fish index (BFI) for the period of 2005-2018.

\subsection{Calculation of the EQR}

We consider that in regard M7, M8, M10, M11, M12 and M13 the present status of the fish assemblage likely does not deviate significantly from the reference status. At present, the most impacted component of the fish fauna could be the littoral species, and especially the phytophilous group, represented by M1 and M2. Phytophilous species has lost more than half of their original habitat area and suffer from habitat degradation in the remaining areas. Regarding the remaining metrics, the fish fauna could moderately deviate from the reference status at the present. The native species are less effected in the offshore area (M4), except the pikeperch (M9). Although there are several non-native species in the lake, their total relative abundance (M3, M5 and M6) is only moderate at the present.

We considered that M1, M2, M3, M4, M6, M8 and M9 could indicate more pronounced effect at the ecosystem level than M5, M7, M10, M11, M12 and M13, and thus, we give them more weight in assessment of the EQR. The scoring guide is presented in Table 2. Additional information on metric values during 2005-2018 and scoring category boundaries are provided in Supplementary Material, Figure S1.

Sum of the scores of the 13 fish-based metrics divided by 100 is the Balaton Fish Index (BFI). BFI represents the EQR of Lake Balaton, values of which may range between 1 corresponding to the reference status and 0 indicating the total loss of the native fauna. The range of the BFI is divided into five equidistant intervals classifying ecological status of Lake Balaton to high (BFI: 0.81-1.00), good (0.61-0.80), moderate (0.41-0.60), poor (0.21-0.40) and bad (0.00-0.20) categories.

For the period of 2005-2018, BFI values ranged between 0.66 and 0.75 indicating good present-day ecological status of Lake Balaton (Fig. 4).

\section{Discussion}

\subsection{Index development}

We developed a fish-based index which can effectively indicate the multiple-pressure ecological alterations in Lake Balaton. The index synthetises information of 13 lake-specific fish-based metrics defined mainly as function of species richness of native assemblages, relative abundance, biomass and age (size) structure of the native key species, representation of non-native elements and general health status. Thirteen metrics is more than the average number of metrics in other fish-based ecological indices (Argillier et al., 2013; Olin et al., 2013; Blabolil et al., 2016, 2017; Virbickas and Stakènas, 2016), but our goal was to establish an index, which could indicate the effect of all major threatening pressures including hydromorphological alterations, non-native fish, eutrophication and fishing/angling (cf. Poikane et al., 2017). Although most aquatic habitats are exposed to multiple pressures, fishbased indexes are usually calibrated to one specific pressure only, most commonly to eutrophication (Argillier et al., 2013; Olin et al., 2013; Blabolil et al., 2016, 2017). Moreover, similarly to the case study on the Srebarna Lake (Pehlivanov et al., 2017), the unique typological status of Lake Balaton did not allow a statistics based metric reduction in the BFI. Our index is based on multiple gear sampling (gillnetting and electric fishing) and combines information of open water and littoral fish assemblages. Similarly to study of Breine et al. (2015), combining data of different fishing methods enabled us to incorporate information on status of the most sensitive and most impacted phytophilous species into the BFI, too.

\subsection{Reference status}

Assessment of the EQR required by the WFD is based on the assumption that we have an exact knowledge on the undisturbed (reference) status of the studied ecosystem to which the present situation could be related (Birk et al., 2012; Poikane et al., 2014). In Lake Balaton, both the original and the present day species pools are well documented. A couple of native phytophilous and benthic species - including crucian carp, weatherfish, spined loach and burbot - disappeared from Lake Balaton by the end of 20th century due to hydromorphological modifications of the littoral zone (specifically rip-rap embankments and separation of lakeside wetland areas and most of inflowing streams from the lake), and as a consequence of the intensive stocking of eel Anguilla anguilla (L.), which lasted from 1961 to 1991 (Bíró, 1997; Specziár, 2010).

On the other hand, we neither have information on nor we could objectively reconstruct the original relative fish abundances of Lake Balaton. Therefore, the sole possibility of defining the reference status in this regard was to make a judgement on how populations of the native key species and the most sensitive phytophilous group would respond for the pass of all human-related pressures. Facts that we considered were: trophic state of Lake Balaton, which determines available food resources, has approached the supposed reference status since late 1990s (Istvánovics et al., 2007); commercial fishing was insignificant for native fish species since the end of 1990s, and fishing was stopped at all in 2013; reproduction of most offshore species is still satisfactory; and the proportion of non-native species has been dropped to a moderate level with the marked decrease of the eel stock and the ban of stocking of bigheaded carp Hypophthalichthys molitrix (Valanciennes) $\times H$. nobilis (Richardson) in the drainage. Therefore, we supposed that of the key native pelagic species, the bleak, the common bream and the razor fish are less effected by anthropogenic pressures, and thus, 
could have a density close to the range of the assumed reference status. On the other hand, population of pikeperch likely is depressed by intensive angling (Specziár and Turcsányi, 2017). On the contrary, as discussed above, both the species richness and the abundance of the phytophilous group could have been much higher in the undisturbed status of Lake Balaton.

\subsection{Metric selection}

Changes in the values of the 13 selected metrics can be related to the four main anthropogenic pressures affecting the ecological status of Lake Balaton. Of pressures, hydromorphological alterations could be listed at first place because of their extended and largely irreversible effect. Draining of wetlands around the lake, regulation of the lake shore and lake side building operations have already caused significant habitat loss and habitat degradation in the littoral area (Virág, 1998), and despite the operative ban this process is likely to continue. Destruction of littoral habitats affects overall biotic diversity, but has only little influence on composition of the open water assemblages in larger lakes (Mehner et al., 2005). Therefore, fish-based monitoring of ecological consequences of hydromorphological alterations requires the inclusion of metrics based on littoral assemblages too, such as on phytophilous species (M2; Jeppensen et al., 2005; Blabolil et al., 2016).

We consider the effect of non-native fishes as the second most dangerous pressure of native fish fauna. In Lake Balaton, introduction of non-native fishes (M3, M5, M6) started in the 1800 s and their regular stocking reached a maximum between 1960s and 1990s (Bíró, 1997). Although stocking of nonnative species is prohibited now, several previously introduced species have established self-sustaining populations in the lake and its catchment (Bíró, 1997; Specziár, 2010). Non-native species with permanent populations are mainly small to medium sized littoral species (M3, M5). On the other hand, the stock size of eel has already been decreased by more than $90 \%$ since the last stocking in 1991, and in the near future, a similar tendency is expected in the stock of the bigheaded carp which rearing was also banned in majority of the drainage (M6).

Worldwide eutrophication of aquatic ecosystems is caused by the increased nutrient load of waters related to human activities. Eutrophication in turn results higher total fish biomass (M11; Launois et al., 2011; Argillier et al., 2013; Olin et al., 2013; Blabolil et al., 2016), mainly due to the increased density of some cyprinids, like for example of common bream (M10; Jeppensen et al., 2000; Mehner et al., 2005; Virbickas and Stakenas, 2016). These relationships were documented also in Lake Balaton as both common bream and total fish biomass increased during the 1970s and 1980s when the lake was hypertrophic, and decreased substantially from the mid1990s, during the re-oligotrophication (Bíró, 1997; Specziár, 2010). On the other hand, there are fish species which do not tolerate lower oxygen concentration, lower visibility and other environmental alterations related to increased lake productivity (Jeppensen et al., 2000). One of these eutrophication sensitive species is the planktivorous razor fish, which density decreased markedly during the hypertrophic period of Lake Balaton (M8; Bíró, 1997).
Following a century of intensive commercial fishery, the objective of fisheries management now is promoting a high but sustainable level angling in Lake Balaton. Commercial fishery primarily targeted common bream (M10), pikeperch (M9) and razor fish (M8) until the 1990s, when it received the task of depleting stocks of the eel and bigheaded carps to its stop in 2013. On the contrary, anglers prefer common carp (M7) and pikeperch (M9). One of the most important consequence of the angling oriented fisheries management is the high rate of common carp stocking amounting ca. 350 tons annually (Specziár and Turcsányi, 2014) and a high harvest rate of pikeperch population (Specziár and Turcsányi, 2017). In sum, both too low or too high biomass values can indicate alteration in the ecological status of the lake, which we tried to incorporate in the BFI in case of these key fish species.

\subsection{Present ecological status of Lake Balaton}

The BFI indicates a good present ecological status of Lake Balaton, and the same result was obtained in each fish survey from 2005. Although some littoral elements of the fauna are impacted and few species have disappeared, the open water assemblage is mainly intact and stable. In the future, a slight increment in the EQR is assumed given that no further degradation in the littoral habitats will occur and the control of non-native stocks will be successful. On the other hand, attaining high ecological status would require a significant habitat reconstruction in the littoral zone and the reestablishment of ecosystem integrity between the lake and surrounding wetland areas.

\subsection{Limits and future perspective}

We appreciate that the suggested methodology is strongly based on the assumption that the reference status of the fish community could be assessed by expert judgement to an acceptable precision. In order to keep this bias at a minimum, we focused on those community traits, which reference levels could be assessed with highest probability and are highly informative as well, such as metrics based on the most abundant key species, the most sensitive phytophilous group of native species and non-native species. A weakness of the proposed index is that due to lack of adequate data, pressure impact relationships could not be investigated. The period covered by fish monitoring data in Lake Balaton is too short to represent significant variations of pressures and fish assemblages. Whereas a comparison to set of other lakes would not be appropriate because of the specific characteristics of Lake Balaton.

It should be noted also that the scoring table of the BFI was calibrated to data provided by gillnetting and electric fishing. However, since gillnetting is an invasive method which damage and kill captured fish, there is a common tendency for restricting its use both in commercial and research fisheries (Winfield et al., 2009; Emmrich et al., 2012). It is likely that with the development of molecular (e.g. environmental DNAbased) and instrumental (e.g. hydroacoustic) techniques, new methods will take over traditional fish sampling in monitoring and call for rethinking the BFI. 
Acknowledgements. We are grateful to all of our colleagues who participated in the fish assemblage monitoring program of Lake Balaton, especially to Ágnes György, Géza Dobos, István Czeglédi, István Tátrai ${ }^{\dagger}$ and Bálint Preiszner. This study was supported by the GINOP 2.3.2-15-2016-00004 project.

\section{References}

Alexander TJ, Vonlanthen P, Periat G, Degiorgi F, Raymond JC, Seehausen O. 2015. Estimating whole-lake fish catch per unit effort. Fish Res 172: 287-302.

Argillier C, Caussé S, Gevrey M, et al. 2013. Development of a fishbased index to assess the eutrophication status of European lakes. Hydrobiologia 704: 193-211.

Birk S, Bonne W, Borja A, et al. 2012. Three hundred ways to assess Europe's surface waters: an almost complete overview of biological methods to implement the Water Framework Directive. Ecol Indic 18: 31-41.

Bíró P. 1981. A Balaton halállományának strukturális változásai. In: Kárpáti I, ed. A Balaton kutatás újabb eredményei II. VEAB Monográfia 16. Veszprém: VEAB, pp. 239-275.

Bíró P. 1997. Temporal variations in Lake Balaton and its fish populations. Ecol Freshw Fish 6: 196-216.

Blabolil P, Logez M, Ricard D, et al. 2016. An assessment of the ecological potential of Central and Western European reservoirs based on fish communities. Fish Res 173: 80-87.

Blabolil P, Ríha M, Ricard D, et al. 2017. A simple fish-based approach to assess the ecological quality of freshwater reservoirs in Central Europe. Knowl Manag Aquat Ecosyst 418: 53.

Breine J, Van Thuyne G, De Bruyn L. 2015. Development of a fishbased index combining data from different types of fishing gear. A case study of reservoirs in Flanders (Belgium). Belg $J$ Zool 145: $17-39$.

CEN 2003. EN 14011:2003. Water quality - Sampling of fish with electricity. Brussels: European Committee for Standardization.

CEN 2005. EN 14757:2005. Water quality - Sampling of fish with multi-mesh gillnets. Brussels: European Committee for Standardization.

Daday J. 1897. XII. Fische (Pisces) In: Entz G, ed. Resultate der Wissenschaftlichen Erforschung des Balatonsees. Wien: Commissionsverlag Von Ed. Hölzel, pp. 216-231.

Deceliere-Vergés C, Argillier C, Lanoiselée C, De Bortoli J, Guillard J. 2009. Stability and precision of the metrics obtained using CEN multi-mesh gillnets in natural and artificial lakes in France. Fish Res 99: 17-25.

EC - European Commission 1992. Council Directive 92/43/EEC of 21 May 1992 on the conservation of natural habitats and of wild fauna and flora. OJEC L206: 7-50.

EC - European Commission 2000. Directive 2000/60/EC of the European Parliament and of the Council of 23 October 2000 establishing a framework for community action in the field of water policy. OJEC L237: 1-72.

EEA 2012. European waters - Assessment of status and pressures. Luxembourg: Office for Official Publication of the European Union.

Emmrich M, Winfield IJ, Guillard J, et al. 2012. Strong correspondence between gillnet catch per unit effort and hydroacoustically derived fish biomass in stratified lakes. Freshw Biol 57: 2436-2448.

Entz G, Sebestyén O. 1942. A Balaton élete. Budapest: Királyi Magyar Természettudományi Társulat.
Erős T, Specziár A, Bíró P. 2009. Assessing fish assemblages in reed habitats of a large shallow lake - a comparison between gillnet sampling and electrofishing. Fish Res 96: 70-76.

Gassner H, Wanzenböck J, Zick D, Tischler G, PammingerLahnsteiner B. 2005. Development of a fish based lake typology for natural Austrian lakes $>50$ ha based on the reconstructed historical fish communities. Internat Rev Hydrobiol 90: 422-432.

Hankó B. 1931. Magyarország halainak eredete és elterjedése. A Debreceni Tisza István Egyetem Állattani Intézetének Közleményei 10.

Herman O. 1887. A magyar halászat könyve. II. kötet. Budapest: A Királyi Magyar Természettudományi Társulat.

Istvánovics V, Clement A, Somlyódy L, Specziár A, Tóth GL, Padisák J. 2007. Updating water quality targets for shallow Lake Balaton (Hungary), recovering from eutrophication. Hydrobiologia 581: 305-318.

Jeppensen E, Jensen JP, Søndergaard M, Lauridsen T, Landkildehus F. 2000. Trophic structure, species richness and biodiversity in Danish lakes: changes along a phosphorus gradient. Freshw Biol 45: 201-2018.

Jeppensen E, Søndergaard M, Jensen JP, et al. 2005. Lake responses to reduced nutrient loading - an analysis of contemporary longterm data from 35 case studies. Freshw Biol 50: 1747-1771.

Karr JR. 1981. Assessment of biotic integrity using fish communities. Fisheries 6: 21-27.

Kelly F, Harrison TD. 2016. The Water Framework Directive: advances in fish classification tools in Ireland. Biol Environ 116B: 205-219.

Launois L, Veslot J, Irz P, Argillier C. 2011. Development of a fishbased index (FBI) of biotic integrity for French lakes using hindcasting approach. Ecol Indic 11: 1572-1583.

Lauridsen TL, Landkildehus F, Jeppesen E, Jørgensen TB, Søndergaard M. 2008. A comparison of methods for calculating Catch Per Unit Effort (CPUE) of gill net catches in lakes. Fish Res 93: 204-211.

Lukács K. 1932. A Balaton halainak gyakoriságáról. Magy Biol Kut Int Munk 5: 17-27.

Mehner T, Diekmann M, Brämick U, Lemcke R. 2005. Composition of fish communities in German lakes as related to lake morphology, trophic state, shore structure and human-use intensity. Freshw Biol 50: 70-85.

Olin M, Rask M, Ruuhijärvi J, Tammi J. 2013. Development and evaluation of the Finnish fish-based lake classification method. Hydrobiologia 713: 149-166.

Pehlivanov LZ, Apostolou AJ, Wolfram G. 2017. Development of Bulgarian Fish Based Index for ecological classification and monitoring of natural riparian lakes (Type L5/L-EC-1). Acta Zool Bulg 8: 153-162.

Poikane S, Zampoukas N, Borja A, Davies SP, van de Bund W, Birk S. 2014. Intercalibration of ecological assessment methods in the European Union: lessons learned and way forward. Environ Sci Pol 44: 237-246.

Poikane S, Birk S, Böhmer J, et al. 2015. A hitchhiker's guide to European lake ecological assessment and intercalibration. Ecol Indic 52: 533-544.

Poikane S, Ritterbusch D, Argillier C, et al. 2017. Response of fish communities to multiple pressures: development of a total anthropogenic pressure intensity index. Sci Tot Environ 586: 502-511.

Pont D, Hugueny B, Rogers C. 2007. Development of a fish-based index for the assessment of river health in Europe: the European fish index. Fish Manag Ecol 14: 427-439. 
A. Specziár and T. Erős: Knowl. Manag. Aquat. Ecosyst. 2020, 421, 11

Prchalová M, Mrkvičká T, Peterka J, Čech M, Berec L, Kubečka J. 2011. A model of gillnet catch in relation to the catchable biomass, saturation, soak time and sampling period. Fish Res 107: 201-209.

Ritterbusch D, Brämick U, Mehner T. 2014. A typology for fish-based assessment of the ecological status of lowland lakes with the description of the reference fish communities. Limnologica 49: 18-25.

Schmutz S, Cowx IG, Haidvogl G, Pont D. 2007. Fish-based methods for assessing European running waters: a synthesis. Fish Manag Ecol 14: 369-380.

Šmejkal M, Ricard D, Prchalová M, et al. 2015. Biomass and abundance biases in European standard gillnet sampling. PLOS ONE: e 0128469.

Specziár A. 2001. A halak mozgási aktivitásának hatása a kopoltyúhálós mintavételezések eredményeire: a CPUE napszakos és évszakos változásai a Balatonban. Hidrol Közl 81: 459-461.

Specziár A. 2010. A Balaton halfaunája: a halállomány összetétele, az egyes halfajok életkörülményei és a halállomány korszerú hasznosításának feltételrendszere. Acta Biol Debr Suppl Oecol Hung 23 (Hydrobiol Monogr vol. 2.): 7-185.

Specziár A, Takács P. 2007. Balaton és befolyói halállományának monitorozása az EU VKI irányelveinek figyelembevételével. In: Mahunka S, Banczerowski J, eds. A Balaton kutatásának 2006. évi eredményei. Budapest: Magyar Tudományos Akadémia, pp. 89-98.

Specziár A, Turcsányi B. 2014. Effect of stocking strategy on distribution and recapture rate of common carp Cyprinus carpio L., in a large and shallow temperate lake: implications for recreational put-and-take fisheries management. $J$ Appl Ichthyol 30: 887-894.

Specziár A, Turcsányi B. 2017. Management of pikeperch stocking in Lake Balaton: effect of season, area, fish size and method of release on the rate and distribution of recaptures. Knowl Manag Aquat Ecosyst 418: 52.
Specziár A, Vörös L. 2001. Long-term dynamics of Lake Balaton's chironomid fauna and its dependence on the phytoplankton production. Arch Hydrobiol 152: 119-142.

Specziár A, Tölg L, Bíró P. 2000. A Balaton halfaunájának vizsgálata. Halászatfejlesztés 24: 115-125.

Specziár A, Erős T, György ÁI, Tátrai I, Bíró P. 2009. A comparison between the Nordic gillnet and whole water column gillnet for characterizing fish assemblages in shallow Lake Balaton. Ann Limnol - Int J Limnol 45: 171-180.

Specziár A, György ÁI, Erős T. 2013. Within-lake distribution patterns of fish assemblages: the relative roles of spatial, temporal and random environmental factors in assessing fish assemblages using gillnets in a large and shallow temperate lake. J Fish Biol 82: $840-855$.

Stoddard JL, Larsen DP, Hawkins CP, Johnson RK, Norris RH. 2006. Setting the expectation for the ecological condition of streams: the concept of reference condition. Ecol Appl 16: 1267-1276.

Unger E. 1925. A Balaton halai és halászata. In: Wlassics T, ed. Balatoni kalauz. Budapest: Balatoni Társaság, pp. 78-88.

Virág Á. 1998. A Balaton múltja és jelene. Eger: Egri Nyomda Kft.

Virbickas T, Stakenas S. 2016. Composition of fish communities and fish-based method for assessment of ecological status of lakes in Lithuania. Fish Res 173: 70-79.

Vutskits GY. 1897. A Balaton halai és gyakoriságuk. Természettud. Közl 29: 593-595.

Winfield IJ, Fletcher JM, James JB, Bean CW. 2009. Assessment of fish populations in still waters using hydroacoustics and survey gill netting: Experiences with Arctic charr (Salvelinus alpinus) in the UK. Fish Res 96: 30-38.

Wootton RJ. 1998. Ecology of teleost fishes. Second edition. Fish and Fisheries Series 24. Dordrecht: Kluwer Academic Publishers.

Zale AV, Parrish DL, Sutton TM. (eds.) 2013. Fisheries techniques, 3rd edition. American Fisheries Society.

Cite this article as: Specziár A, Erős T. 2020. Development of a fish-based index for the assessment of the ecological status of Lake Balaton in the absence of present day reference condition. Knowl. Manag. Aquat. Ecosyst., 421, 11. 
A. Specziár and T. Erős: Knowl. Manag. Aquat. Ecosyst. 2020, 421, 11

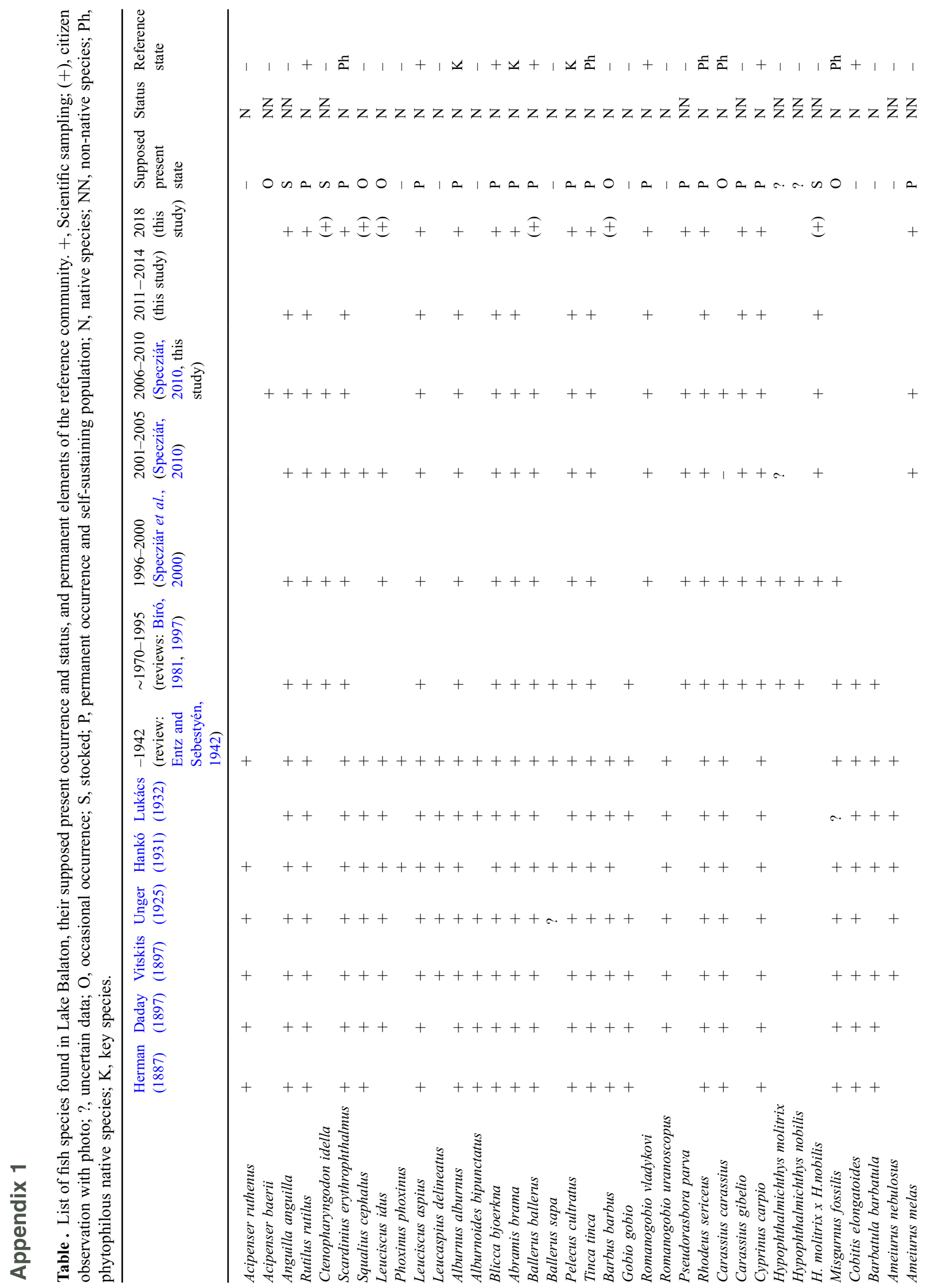


A. Specziár and T. Erős: Knowl. Manag. Aquat. Ecosyst. 2020, 421, 11

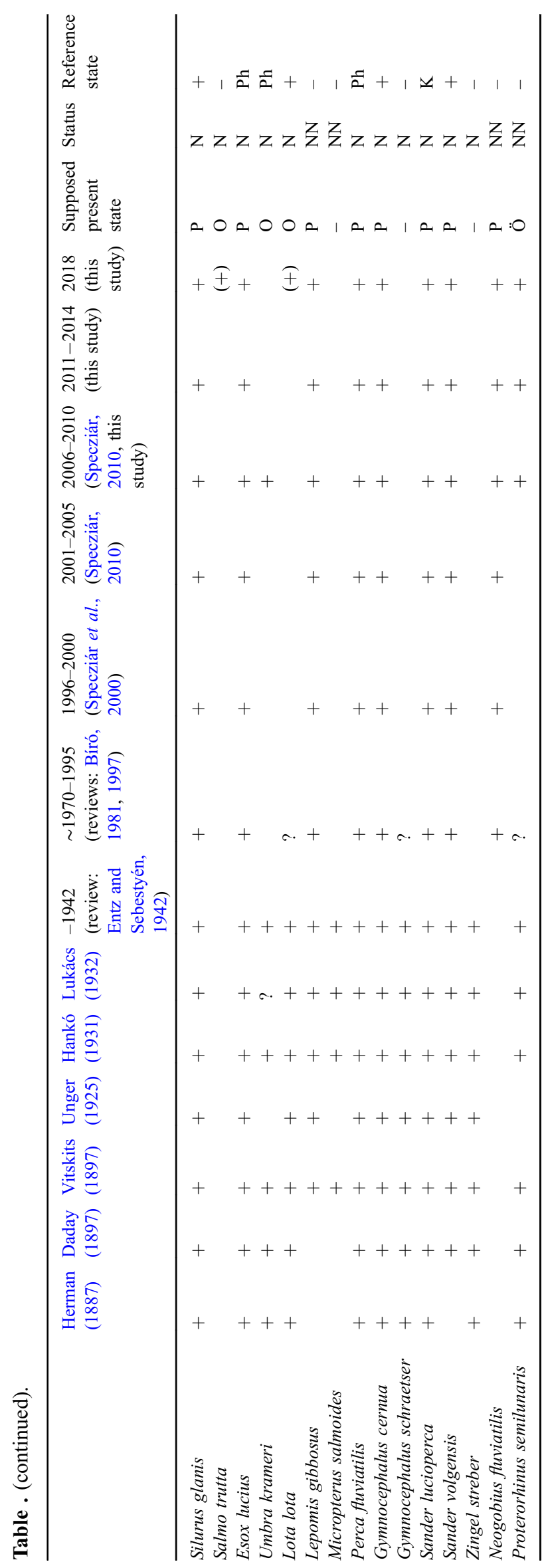

